\title{
Service Sector Growth in China and India: A Comparison
}

\author{
Yanrui Wu \\ School of Economics and Commerce \\ University of Western Australia \\ 35 Stirling Highway, Crawley WA 6009 \\ Australia \\ yanrui.wu@uwa.edu.au
}

\begin{abstract}
$\underline{\text { Abstract }}$ China and India have recently achieved spectacular economic growth. However, services in these two Asian giants have played a very different role. In India, the service sector contributes to more than 54 per cent of GDP while its GDP share in China is much smaller (below 41 per cent in 2004). To provide an explanation for the contrasting trajectories, this paper examines and compares service sector developments in these two Asian giants. It investigates the determinants of demand for services and sheds light on the outlook for service sector growth in the two countries.
\end{abstract}

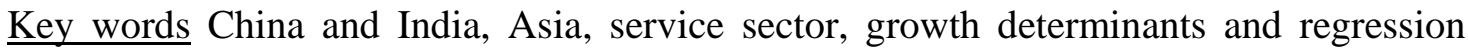
analysis

(forthcoming in China: An International Journal) 


\section{Service Sector Growth in China and India: A Comparison ${ }^{1}$}

Since the early 1990s, the world has witnessed the spectacular growth of the economies of China and India (at the average annual rate of 10.2 and 6.2 per cent, respectively, during the period of 1992-2005). ${ }^{2}$ Associated with this growth is the dramatic development of the service sectors in the two Asian giants. However, a comparison of the economic structure in China and India demonstrates that the role of the service sector (or the tertiary sector as it is known in China) in the two economies is very different (see Figure 1). On the one hand, the service sector has become the dominant contributor to the Indian economy, accounting for 54.2 per cent of GDP in 2004. ${ }^{3}$ The success in this sector is regarded as “India's services revolution” (Gordon and Gupta 2004). On the other hand, China's service sector has lagged well behind the manufacturing sector (or the secondary sector according to Chinese terminology), and its role in the economy improved slightly in the last fifteen years when the Chinese economy achieved its best performance in recent history. During 1990-2004, for example, the service sector GDP as a proportion of China's GDP increased modestly from 34.3 per cent in 1990 to 40.7 per cent in 2004 according to Figure 1. Why have the two countries taken very different trajectories in developing their service economies? What are the implications for future developments in the two Asian giants? Which factors affect demand for services in China and India? These are some of the questions which are investigated in this paper.

There is hardly any comparative study of services in China and India. However, several studies focused on the service sector in individual countries. For example, Gupta (1998)

\footnotetext{
${ }^{1}$ The first draft of the paper was completed while the author was visiting the East Asian Institute, National University of Singapore. The author is grateful to EAI and its Director (Professor Wang Gungwu) and Research Director (Professor John Wong) for the generous support provided. He also thanks three anonymous referees, Elspeth Thomson and participants at an EAI seminar for helpful comments and suggestions.

2 The average growth rates are based on data from the Reserve Bank of India (2005), the National Bureau of Statistics (2005) and China's newly released economic survey results (www.stats.gov.cn). China conducted a nation-wide economic survey in 2005. The survey results released in January 2006 show that China's GDP in 2004 was underreported by 16.8 per cent (Zhu 2005). The discrepancy was mainly due to underreporting of service sector economic activities. Chinese government subsequently revised and released the country's historical GDP statistics back to 1993 (www.stats.gov.cn). Where possible, the newly released data are employed in this study.

${ }^{3}$ This is based on revised estimate by the Reserve Bank of India (2005).
} 
and Mohan (1998) examined productivity in Indian service sector in comparison with other Asian economies, Chanda (2002) discussed service trade in the world particularly in India and its implications for the WTO negotiations in services, Gordon and Gupta (2004) presented a detailed study explaining India's service growth in the past decade. Examples of studies on China include $\mathrm{Li}$ and Hou (2003) who presented an edited volume on China's WTO entry and its implication for the service sector, Jiang (2004) who edited a book focusing on growth and structural changes in services with some marginal coverage of international comparison and $\mathrm{Li}$ (2004a, 2004b) conducted a comprehensive investigation of China's service sector. This study extends the existing literature by comparing growth in and demand for services in China and India.

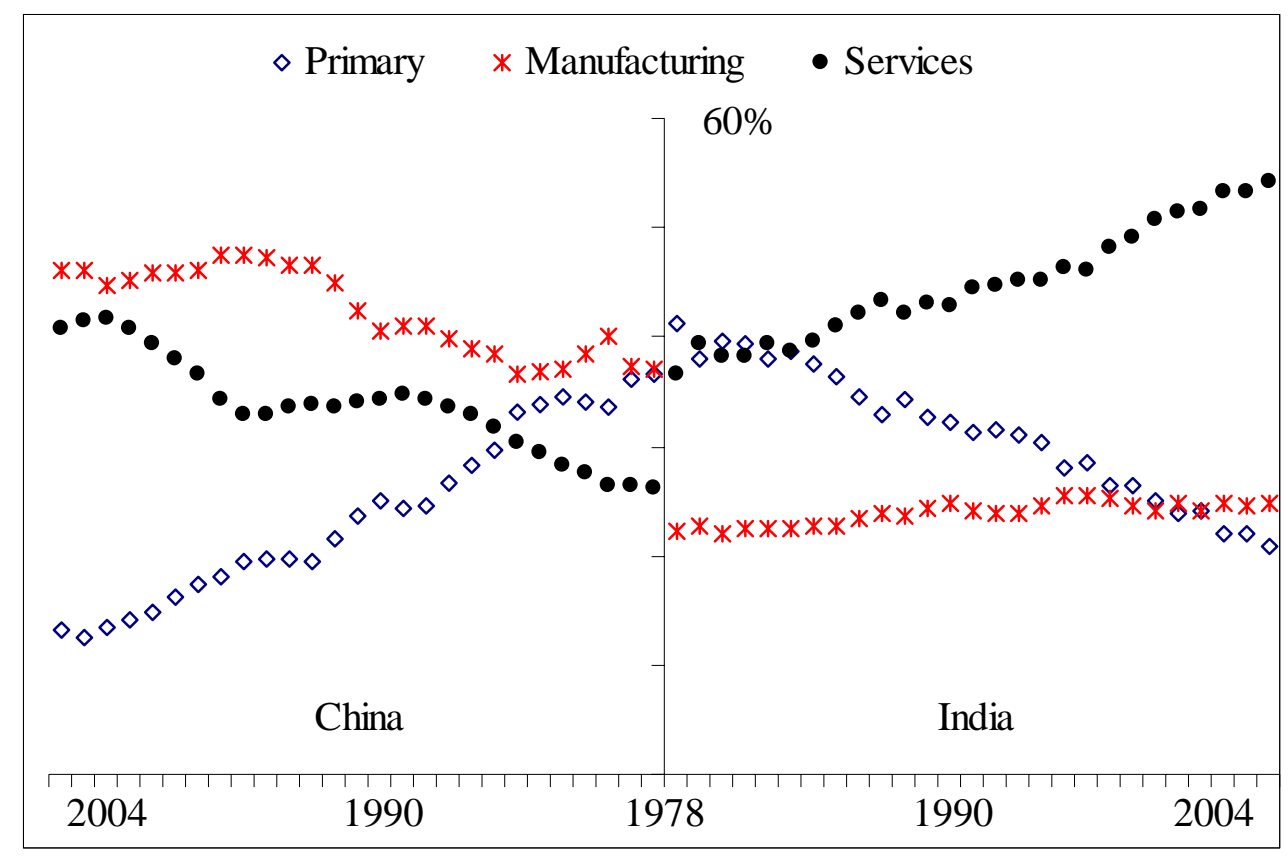

Notes and sources: National Bureau of Statistics (various issues) and Reserve Bank of India (2005). Chinese data from 1993 onwards are revised according to China's recently released economic survey results (www.stats.gov.cn, Zhu 2005).

Figure 1 GDP shares by sector in China and India, 1978-2004

The rest of the paper begins with a brief review of developments in the service sector in China and India. This is followed by discussion of the determinants of the demand for services. Three empirical models are employed to examine the factors affecting demand 
for services internationally as well as in China and India. Subsequently, the paper discusses the growth outlook of services in the two countries. The final section summarizes the findings.

\section{SERVICE SECTOR DEVELOPMENT}

Following the conventional classification, an economy is divided into three sectors, that is, agricultural (or primary), manufacturing (or secondary) and service (or tertiary) sectors. The agricultural sector consists of farming, forestry, animal husbandry and fishery. The manufacturing sector is composed of mining, construction and manufacturing. ${ }^{4}$ All other economic activities which are not covered by the agricultural and manufacturing sectors are broadly defined as services and hence belong to the service sector. They include services provided for the agricultural sector, activities associated with the supply of water, electricity and gas, transport and communications, wholesale and retail trade, finance and insurance, business and personal services, and community and social services. Services can be broadly distinguished between two types, that is, the old and new services. The old or traditional services include petty trading, domestic services, catering and hotel services. The new services are generally associated with communications, business and legal practice, culture, research and education. ${ }^{5}$ The latter are tradable internationally and hence are also called tradable services.

\section{Service Sector Growth}

The service sector in China and India has achieved high growth with an average annual rate of 10.8 percent in China and 7.0 per cent in India during the period of 1978-2004. ${ }^{6}$

\footnotetext{
${ }^{4}$ Whether services include construction and public utilities is controversial (Ochel and Wegner 1987). Construction and public utilities are treated as part of services according to the Indian classification as well as the World Bank (2005). The Chinese classification excludes construction and public utlities from services. OECD (2005) also excludes construction from services. This paper follows the OECD system which includes construction in the manufacturing category.

${ }^{5}$ Luo (2001) provided a detailed survey of the main service sectors in particular the new service sectors in China.

${ }^{6}$ India's growth rate is based on the financial years of 1978/1979-2004/2005 (Reserve Bank of India 2005). The Chinese rate is calculated using data from the National Bureau of Statistics (various issues) and the recently released economic survey results (www.stats.gov.cn).
} 
The gap between the growth rates matches the difference in the rates of GDP growth in the two countries. During the same period, an average annual growth rate of 9.7 per cent was recorded for the Chinese economy while the same rate was 5.4 per cent for India. ${ }^{7}$ At the disaggregate level, the structure of the service sector in China and India is very similar. It is still dominated by the traditional or old services, followed by business services (finance, insurance and real estate) and transport and communications according to Table 1. However, the new service sectors are catching up rapidly. During 1999-2003, communication services achieved the strongest growth in both countries (with a average annual rate of 16.77 per cent in China and 23.89 per cent in India), followed by education (8.59 per cent) and research (11.94 per cent) in India and real estate (8.75 per cent) and research (8.93 per cent) in China. ${ }^{8}$ Though growing rapidly in recent years, researchrelated services are still relatively small in both countries according to Table 1 . The same table also shows that, in comparison with other major economies, services in the areas of real estate, health, sports and social welfare in both China and India are relatively weak.

Table 1 Composition of Service Sector GDP (2003, \%)

\begin{tabular}{lrrrrrrr}
\hline Service Sectors & China & India & Australia & Korea & Japan & UK & US \\
Finance and Insurance & 16.50 & 13.27 & 11.83 & 15.53 & 9.78 & 6.89 & 10.35 \\
Government and Social Organizations & 8.01 & 10.78 & 6.06 & 10.47 & 6.72 & 6.62 & 10.35 \\
Real Estate & 6.07 & 11.64 & 29.15 & 22.34 & 30.66 & 32.16 & 30.92 \\
Wholesale, Retail Trade and Catering & 23.57 & 30.39 & 19.15 & 17.98 & 18.54 & 20.81 & 20.05 \\
Transport, Telecommunications etc & 16.96 & 19.18 & 12.11 & 13.09 & 8.91 & 10.00 & 7.89 \\
$\quad$ Transport and Storage & 8.76 & 10.86 & & & & & \\
$\quad$ Post and Telecommunications & 8.20 & 8.32 & & & & & \\
Education, Health, Research etc & 28.87 & 14.73 & 21.69 & 20.59 & 25.40 & 23.51 & 20.44 \\
$\quad$ Education, Culture and Arts & 8.71 & 7.98 & & & & & \\
$\quad$ Health, Sports and Social Welfare & 2.96 & 2.14 & & & & & \\
$\quad$ Scientific Research and Polytechnic & 2.25 & 0.89 & & & & & \\
$\quad$ Others & 14.95 & 3.71 & & & & & \\
Total & 100 & 100 & 100 & 100 & 100 & 100 & 100 \\
\hline
\end{tabular}

Notes and sources: China's "Others” category may contain items which belong to the "Wholesale, Retail Trade and Catering” group. Data are drawn from the National Bureau of Statistics (various issues), OECD (2005) and CSO (2005).

\footnotetext{
${ }^{7}$ These growth rates are derived using data from the Reserve Bank of India (2005) and National Bureau of Statistics (various issues) including the recently released economic survey results (www.stats.gov.cn).

${ }^{8}$ These rates of growth are calculated using data from the CSO (2005) and National Bureau of Statistics (various issues) including the recently released economic survey results (www.stats.gov.cn).
} 


\section{Output and Employment Shares}

The development of the service sectors can also be examined by analyzing the sectoral shares of output and employment over the national totals in the two countries. Output shares of the service sector in China and India have grown steadily since 1978 as shown in Figure 2. ${ }^{9}$ The role of services in the Indian economy is clearly more significant than that of services in the Chinese economy. Accordingly, since 1990, India’s service sector has grown faster (with an annual rate of 7.5 per cent) than the manufacturing sector (with an annual rate of 6.0 per cent) while the opposite is true in China where the manufacturing sector with an average rate of growth of 12.1 per cent has outpaced the growth of the service sector (at the rate of 8.4 per cent). ${ }^{10}$

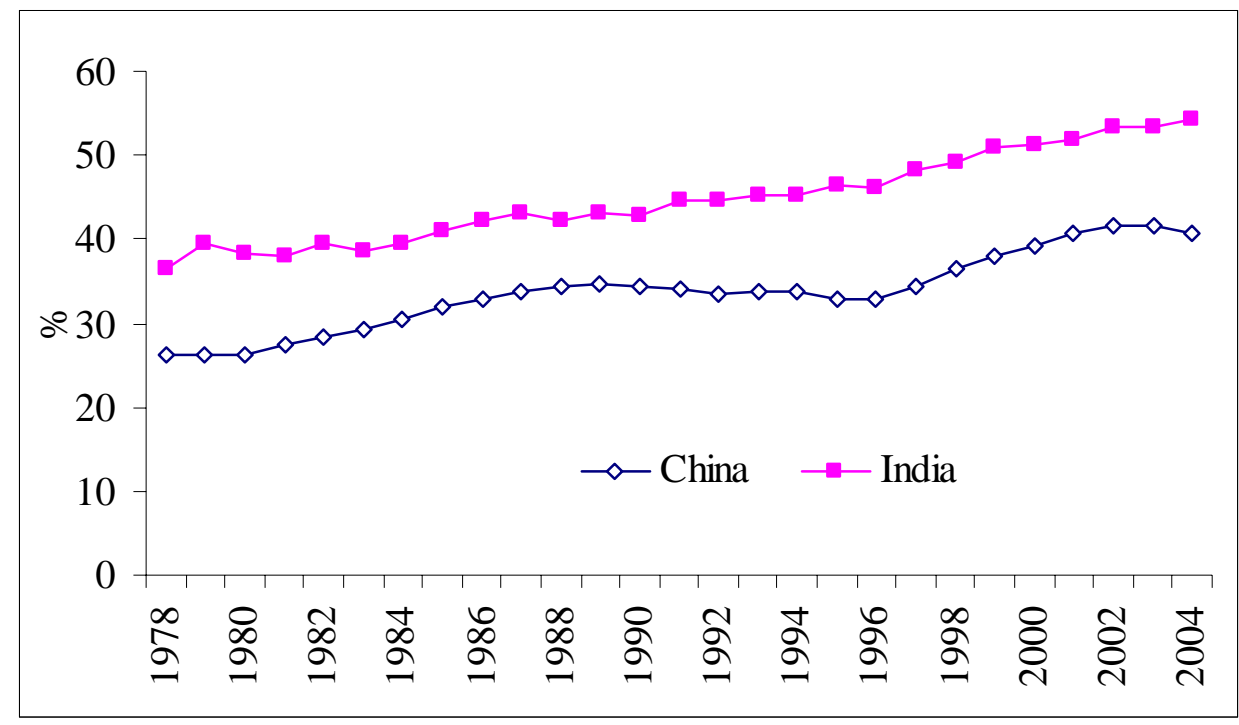

Notes and Sources: Data are drawn from the National Bureau of Statistics (various issues) and Reserve Bank of India (2005). Chinese data from 1993 onwards are revised according to China's recently released economic survey results (www.stats.gov.cn).

Figure 2 Service Sector Share over Total GDP, 1978-2004

\footnotetext{
${ }^{9}$ China's figures are based on the recently released economic survey results which show that service activities are substantially under-reported.

${ }^{10}$ These growth rates are based on data from the Reserve Bank of India (2005) and National Bureau of Statistics (various issues) including the recently released economic survey results (www.stats.gov.cn).
} 
In contrast, the employment share of India's service sector has grown very slowly according to available statistics covering the period of 1983-1999 though its absolute figure was much higher than China's in the 1980s (Figure 3). The employment share of China's service sector has however been growing steadily since 1978, in particular since the early 1990s. As a result, China's service sector has absorbed relatively much more labour force than India's since the mid-1990s. In terms of creating new jobs, services have played a vital role in both economies. For example, during the decade of 1995-2004, more than 62 per cent of new jobs were created in China's service sector while India's services provided about 54 per cent of new jobs in the country during the period of 19941999. ${ }^{11}$ As both countries have to relocate a large pool of rural surplus labour, further growth in employment in the service sector will be indispensable.

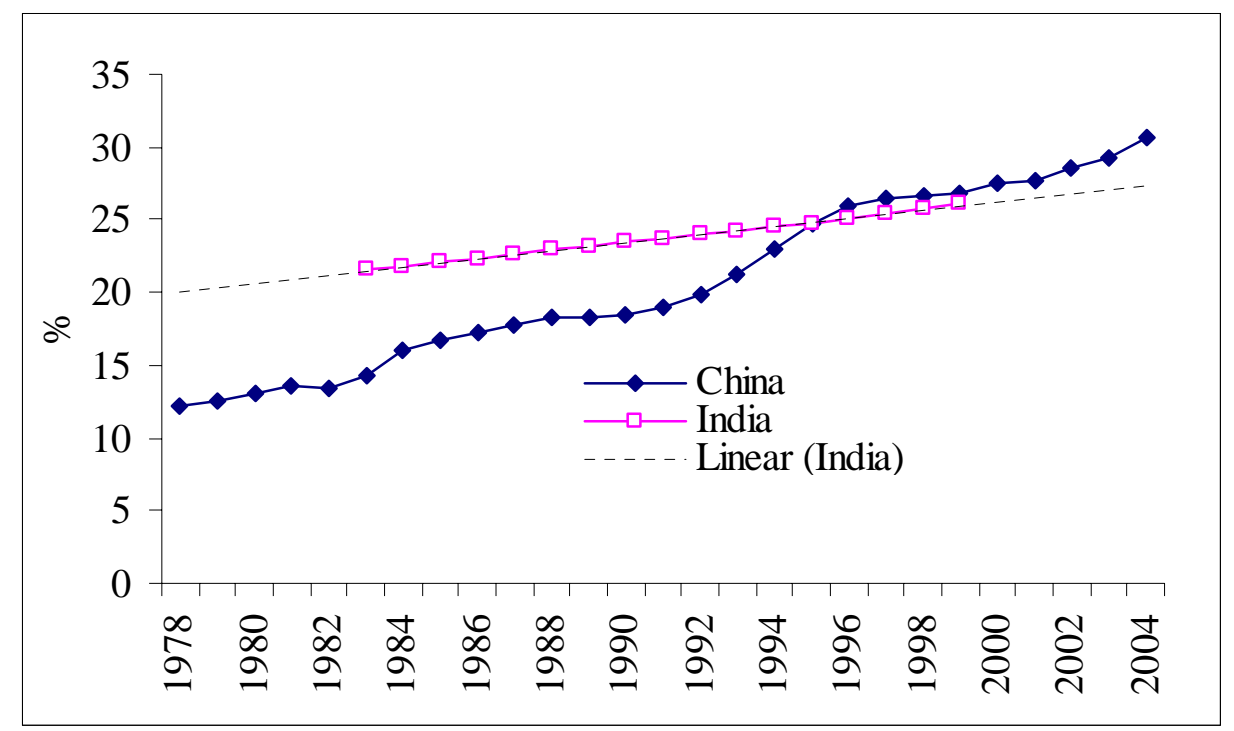

Notes and sources: Data are drawn from the National Bureau of Statistics (various issues) and Reserve Bank of India (2005). India data are available for the period of 1983-1999 only. The dashed line approximates the missing observations.

Figure 3 Employment shares of the Service Sectors, 1978-2004

\footnotetext{
${ }^{11}$ These numbers are derived using data from the National Bureau of Statistics (various issues) and Reserve Bank of India (2005).
} 


\section{Regional Variations}

In terms of the level of development of the service sector, there is considerable variation across the regions in both countries. ${ }^{12}$ "Regions" here are defined according to the official administrative units, that is, they mean China's provinces, autonomous districts and municipalities and India's union states and territories. Several observations about service development among the regions can be made. First, regional development in services follows the national trend. In general, the service sectors at the regional level in India are on an average more developed than those in China. For example, Beijing has China's most advanced service sector which has a GDP share of 61 per cent in 2001 while Delhi has India's most advanced service sector with a GDP share of 77 per cent in the same year according to Figures 4 and $5 .{ }^{13}$ Second, the service sector tends to be more important among relatively more developed regions in both countries. Figures 4 and 5 show clearly a positive relationship between the level of service sector development and GDP per capita in both Chinese and Indian regions. Finally, the service sector plays a more important role in regions where the level of urbanization is high, such as Delhi and Chandigarh in India and Beijing and Shanghai in China.

\section{Growth in International Perspective}

The experience of economic development shows that, while a country expands its manufacturing capacity, the agriculutral sector in the economy declines relatively, and that over time the service sector grows and eventually overtakes the manufacturing sector to become the dominant part of the economy (Figure 6). For example, the GDP share of services over national total in 2003 amounted to 71 per cent in Australia, 72 per cent in the United Kingdom and 75 per cent in the United States (World Bank 2005). The process of changes follows the stages of economic development. However, in comparison with countries at the similar stage of development, China's service sector development is

\footnotetext{
${ }^{12}$ Wong and Liang (2003a) examined regional variation in China's service development.

${ }^{13}$ The service sectors at the regional level in China are likely to be underreported given the fact that data at the national level are underreported substantially. However, regional revised data are not available yet.
} 


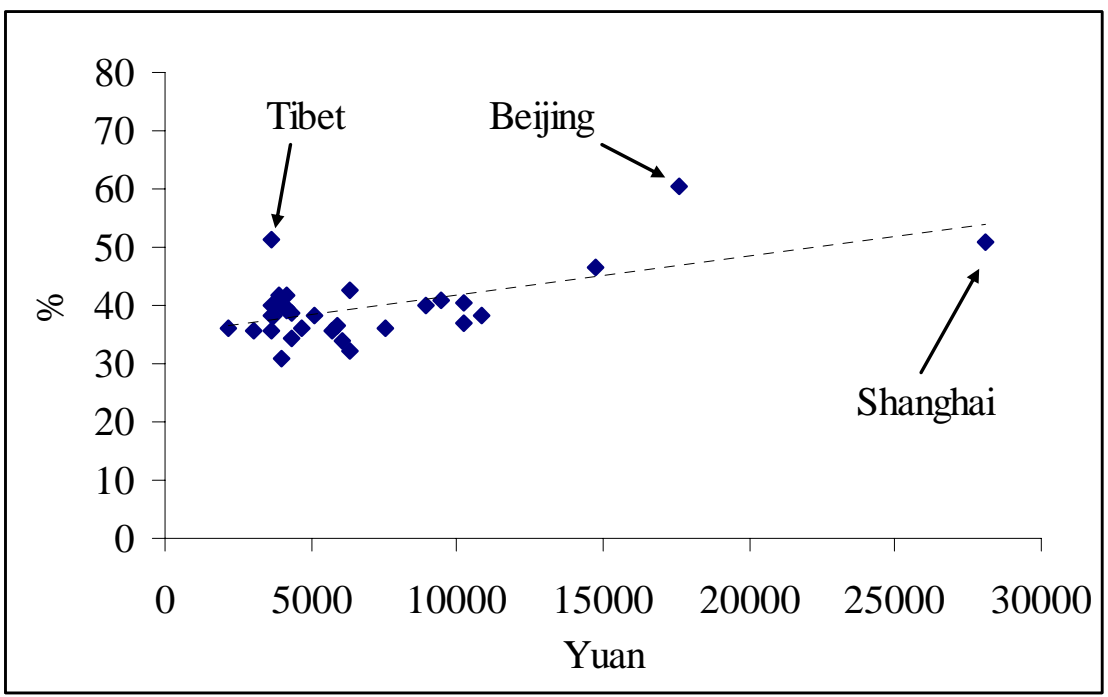

Notes and sources: Data are drawn from the National Bureau of Statistics (various issues). The dashed line represents the fitted regression line. In 2001, US\$1= 8.277 Chinese yuan.

Figure 4 GDP per capita and Service Sector GDP Shares in Chinese regions, 2001

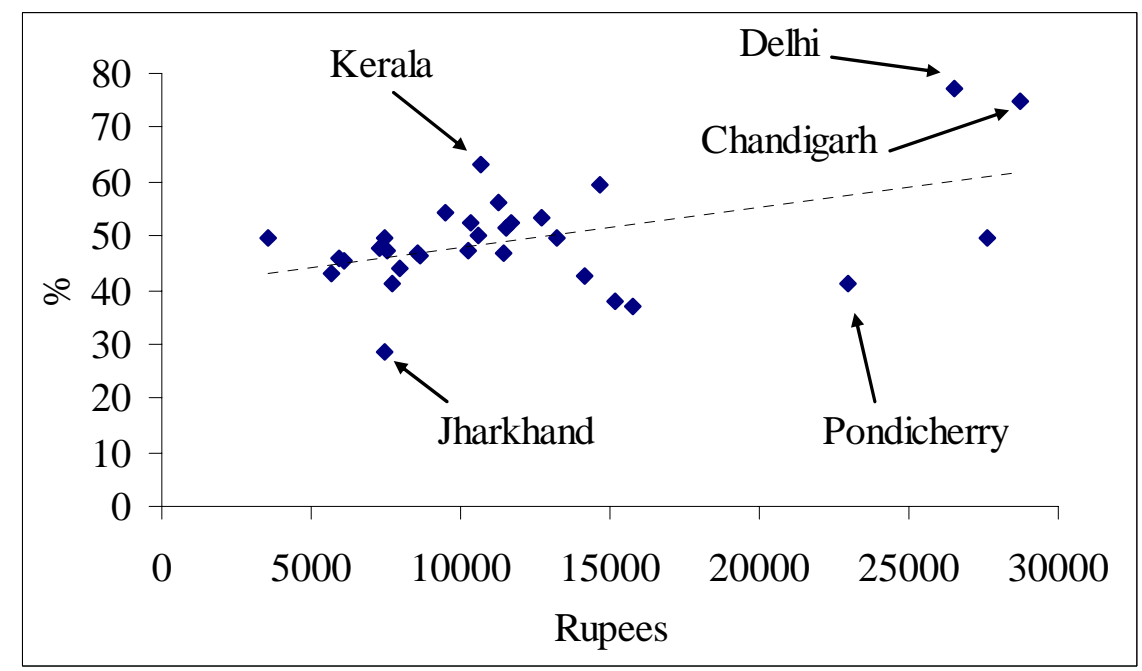

Notes and source: Data are drawn from the Reserve Bank of India (2005).The dashed line represents the fitted regression line. In 2001, US $\$ 1=47.186$ rupees.

Figure 5 GDP per capita and Service Sector GDP Shares in Indian regions, 2001 


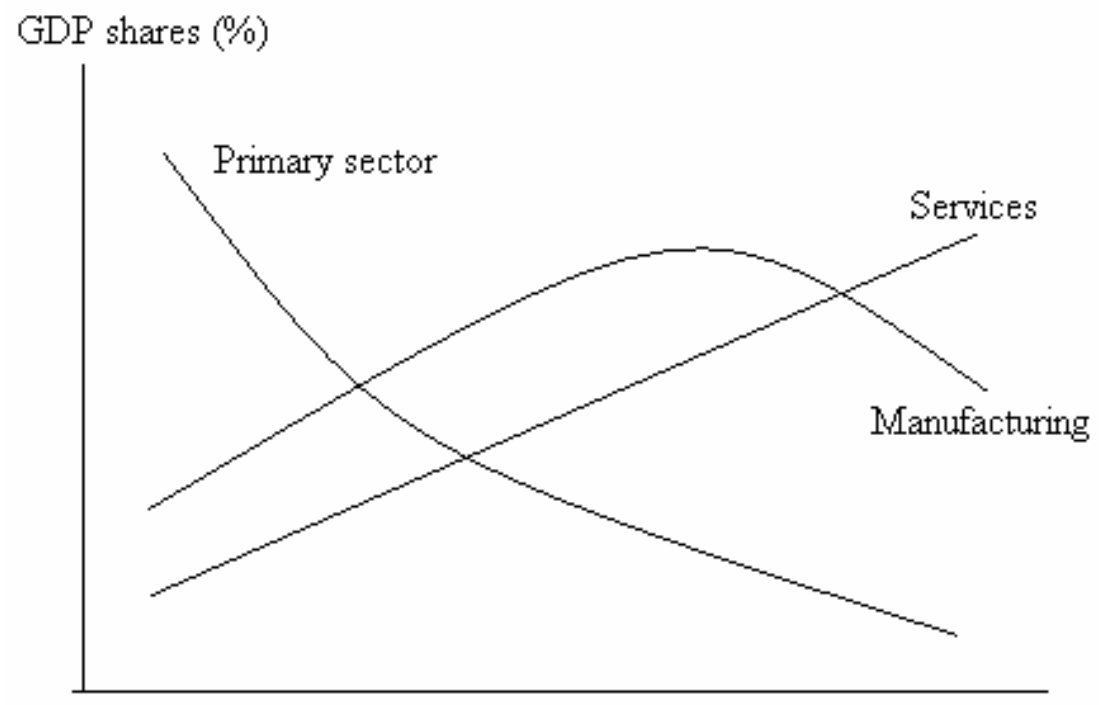

Level of income

Figure 6 Economic Structure and Level of Development

slightly below the average while India's is slightly above the average. These are clearly demonstrated in Figure 7 which illustrates service sector GDP shares against per capita income among the nations with per capita GDP less than US\$2000 in 2003. Information at the disaggregate level also implies that services in China and India are still at the early stage of development which is represented by the dominance of the old services and weakness in real estate, education and research services (Table 1).

The relative backwardness of services in China is also reflected in the role of service trade. In 2003, China was the world's fourth largest merchandise exporter but its service export was only ranked the $10^{\text {th }}$ (World Bank 2005). The share of service exports over total exports in China (9.6 per cent in 2003) was much smaller than 28.4 per cent in the United States, 32.4 per cent in the United Kingdom, 22.4 per cent in Australia, 13.9 per cent in Japan and 18.6 per cent in the world as a whole during the same period. ${ }^{14}$ Not surprisingly, China is currently a net importer of services. In contrast, India's service exports accounted for 30.9 per cent of total exports in 2003 making the country a net exporter of services according to the World Bank (2005). This is largely due to India's

\footnotetext{
${ }^{14}$ These shares are derived using data from the World Bank (2005).
} 
success in IT service exports and India's relatively small value of merchandise exports (equivalent to only 12 per cent of China's in 2003). In 2003 India’s total merchandise export was ranked $31^{\text {st }}$ in the world but its service export was ranked $20^{\text {th }}$ (World Bank 2005). In addition, among the service exports, finance and insurance share in 2003 only amounted to 1.0 and 1.5 per cent in China and India, respectively, while this share was 7.8 per cent in the United States and 22.6 per cent in the United Kingdom in the same year according to the World Bank (2005).

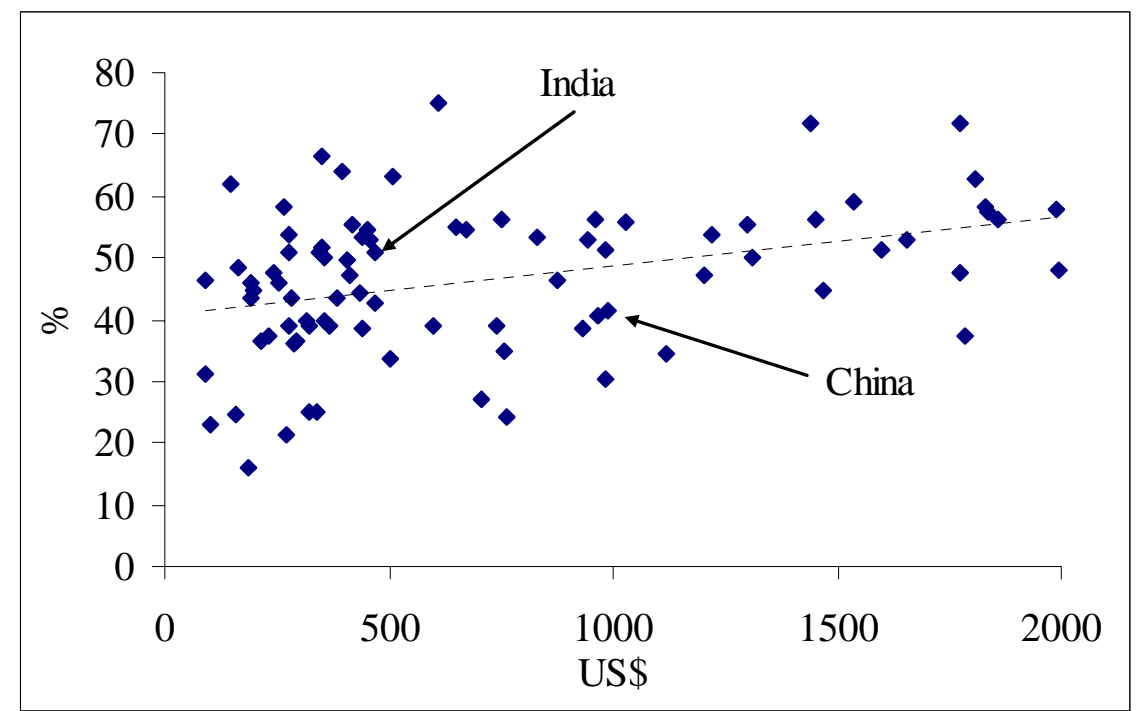

Notes and sources: Data are drawn from the World Bank (2005). The dashed line represents the fitted regression line. Chinese data is based on the country's recently released economic survey results (www.stats.gov.cn).

Figure 7 Service Sector Shares and GDP per capita across Countries, 2003

To sum up, the service sector as part of the national economy in China and India has achieved substantial growth in recent decade. However, in international perspective, China and India are outliers, ie. India's service sector over-performed while China's is an underachiever. In addition, new services are still weak in both China and India with the exception of India's IT export sector. At the regional level in each country, the pattern of service development is similar to the national trend. In particular, service development seems to be closely related to the level of urbanization. These features are further explored in the following sections. 


\section{DETERMINANTS OF GROWTH}

\section{The Theory}

It is argued that growth of the service sector is determined by several factors such as production specialization, income level and urbanization (Mulder 2001, Wolfl 2005). These factors are interrelated. As an economy grows, productive activities become more specialized and urbanization accelerates due to the rising level of income. In the meantime, as a result of the increasing specialization of production, firms tend to outsource many service activities such as legal, accounting and security services. Some authors call this process the specialization splintering (Bhagwati 1984). It is the main source of demand for services from the producers.

At the household level, Engel's law shows that, as income rises, consumption of food and durable goods in turn becomes saturated over time and demand for services such as healthcare, travel, communications and finance increases. Growth in income also boosts demand for away-from-home consumption of food and services.

Furthermore, urbanization contributes to the growth of the service sector in two ways. Unlike farmers who to some extent can provide self-services, urban consumers rely on the market for the supply of services. They are also more likely to enter the urban informal sector for employment if there are no job opportunities in the formal sector. Services account for the lion's share of the informal sector. Thus, urban residents are both consumers and suppliers of services. It is expected that the service sector grows as the level of urbanization increases in a society. This is confirmed by preliminary analysis of both China's and India's regional data in the preceding section.

In addition, the participation of women in the workforce has an impact on service demand as well. More women in the workforce could lead to an increase in demand for services, ranging from babysitting and catering to tuition and beauty treatments. Furthermore, regulatory policies also affect the development of the service sector. A good 
example is the rapid growth of telecommunications services after deregulation in many countries (Wirtz 2002). This phenomenon can be repeated in other areas such as insurance, banking, health care and so on. Regulatory environments can also affect international trade and foreign investment in services (Mulder 2001). Finally, apart from the factors discussed above, service sector growth in China and India may also be affected by development strategy and historical experience. ${ }^{15}$ Divergence in the latter may contribute to the different role of services in the two countries. For example, India's service industry may benefit from the country's early and prolonged linkage with the West, in particular the UK. In the meantime, after the communist government took office in 1949, China adopted a biased policy towards the development of the heavy industry initially and labour-intensive manufacturing more recently while rural-urban labour movement was restricted for a long time and hence entry into the service sector (mainly old services) was very limited. Thus, for decades, China’s development policy has been anti-services, and is hence partly responsible for the country's underdevelopment of the service industry. In the empirical analysis presented in the following section, the factors discussed so far would be taken into consideration so long as quantification is possible.

\section{The Empirics}

To examine the determinants of growth in services in China and India, three models are considered, and they are applied to Chinese provincial, Indian state and cross country databases, respectively. The econometric model can be expressed as follows

$$
S E R=\alpha+\sum \beta_{j} X_{j}+\varepsilon
$$

where SER and $X$ represent demand for services and a list of factors affecting service demand, respectively. $\alpha$ and $\beta$ are coefficients to be estimated. $\varepsilon$ is the standard error term. Equation (1) can be applied to either panel data for the country models or crosssection data for cross-country analysis. For panel data models, several optional models

\footnotetext{
${ }^{15}$ Desai(2003) presented an interesting piece comparing the economies of China and India from the perspective of political economy.
} 
are considered eg. without group dummy (the same intercept for all groups), fixed effect (different intercept for each group) and random effect models (intercepts vary by a random error).

SER in equation (1) is measured as the GDP share of services in a country or region. The choice of the variables $(X)$ in the models is dictated by the availability of data. In the three optional models considered here, $\mathrm{X}$ includes per capita income (I), urbanization $(\mathrm{U})$, service export shares in total exports (EX) and the proportion of women in total nonfarming workforce (W). EX and $\mathrm{W}$ are not available for the regions of China and India, and hence incorporated in the cross-country model only. The Chinese data cover thirtyone regions and the period of 1993-2003. The Indian statistics are available for thirty-one union states and territories out of thirty-five for nine years (1993-2001). The crosscountry database has one year (2003) data for ninety-three countries. The estimation results are reported in Table 2.

According to Table 2, the estimated coefficients of both per capita income (I) and urbanization (U) are positive and statistically significant. It implies that both variables are important factors affecting the development of the service sector among the countries especially in China and India. In addition, it is found that external demand also has a positive impact on service development among the countries. This partly explains the phenomenal growth of IT service exports in India. The cost of services is shown to have a negative effect but the estimated coefficient is statistically insignificant. Thus, further investigation is needed. The findings here are of course subjected to qualifications due to the limitation of data.

\section{GROWTH OUTLOOK}

Both the Chinese and Indian economies have entered the phase of rapid growth. The consensus view is that this growth will last for decades (Wilson and Purushothaman 2003, Li et al. 2006). It is thus anticipated that per capita income in both countries will 
Table 2 Estimation Results

\begin{tabular}{|c|c|c|}
\hline & Fixed effect & Random effect \\
\hline \multicolumn{3}{|l|}{ Chinese model } \\
\hline Income per capita & $0.00059(6.20)^{*}$ & $0.00059(6.32)^{*}$ \\
\hline Urbanization & $0.15939(5.54)^{*}$ & $0.14896(5.40)^{*}$ \\
\hline Intercept & $27.94560(28.74)^{*}$ & \\
\hline $\bar{R}^{2}$ & 0.87 & \\
\hline Log-likielihood & -732.5 & \\
\hline No. of observations & 341 & 341 \\
\hline \multicolumn{3}{|l|}{ Indian model } \\
\hline Income per capita & $0.00062(3.19)^{*}$ & $0.00060(3.56)^{*}$ \\
\hline Urbanization & $0.24797(4.95)^{*}$ & $0.24620(5.47)^{*}$ \\
\hline Intercept & 34.35820 (33.67) & \\
\hline $\bar{R}^{2}$ & 0.492 & \\
\hline Log-likielihood & -848.3 & \\
\hline No. of observations & 252 & 252 \\
\hline \multicolumn{3}{|l|}{ International model } \\
\hline Income per capita & \multicolumn{2}{|c|}{$0.00056(3.45)^{*}$} \\
\hline Urbanization & \multicolumn{2}{|c|}{$0.17346(2.94) *$} \\
\hline Cost & \multicolumn{2}{|c|}{$-23.72770(-1.11)$} \\
\hline Service exports & \multicolumn{2}{|c|}{$0.11245(1.72)^{* *}$} \\
\hline Intercept & \multicolumn{2}{|c|}{$38.31050(11.15)^{*}$} \\
\hline $\bar{R}^{2}$ & \multicolumn{2}{|c|}{0.40} \\
\hline No. of observations & \multicolumn{2}{|l|}{93} \\
\hline
\end{tabular}

Notes: The simple version of the country models without group dummy was estimated and rejected according to a $\chi^{2}$ test. The estimation results are not reported in this table. The numbers in parentheses are the t-values. ${ }^{*}$ and ${ }^{* *}$ indicate significance at the level of $1 \%$ and $10 \%$, respectively.

rise over time and subsequently urbanization will accelerate. These factors imply that the service sector in China and India will expand further. This growth will also be boosted by globalization. From 2006 onwards, China's WTO commitments will allow greater foreign participation in the service sector including telecommunications, banking and insurance and so on (Wong and Liang 2003b). Economic openness will also create more jobs for accountants, lawyers and other financial specialists (Luo 2001). Further economic liberalization and deregulation in India will ensure sustained growth including 
growth in services. Both China and India will also benefit from WTO's general agreement on trade in services (GATS). ${ }^{16}$ Therefore growth prospect for services in both countries looks bright. In particular, growth in services in the two countries will be associated with the following features.

Service sector growth in China will continue and the manufacturing sector will remain its dominance in the economy. Both sectors will show some gain in terms of GDP and employment shares at the expense of agriculture. One source of forecasts, for example, implies that the GDP shares of the agricultural, manufacturing and service sectors in 2020 will be 5.0, 45.8 and 49.2 per cent, respectively, and in the meantime, the employment shares will be 34.2, 22.4 and 43.4 per cent, respectively. ${ }^{17}$ By then, China’s service sector will be bigger than the manufacturing sector. However, China will still be a long way to catch up with the advanced economies in the world. For instance, the service sector in 1997 accounted for 58 per cent of total GDP in Japan, 64 per cent in the US, 53 per cent in Germany and 60 per cent in the UK while the employment share in the same year was 62 per cent in Japan, 74 per cent in the US, 62 per cent in Germany and 72 per cent in the UK, respectively (see Table 3). Currently, the service sector contributes to China's economic growth largely due to the shift of labour from agriculture into services (Qin 2004). This shift of labour will eventually be replaced by the shift from the manufacturing to services.

\footnotetext{
${ }^{16}$ For detailed discussion of GATS' impacts on service trade, see Li and Hou (2003) on China and Chanda (2002) on India.

${ }^{17}$ The output share estimates are based on the recently released economic survey data and forecasts by Li et al (2006) who predicted that the GDP shares of the primary, manufacturing and service sectors in 2020 would be 7.1, 52.5 and 40.4 per cent, respectively. The employment shares are the original forecasts by $\mathrm{Li}$ et al. (2006).
} 
Table 3 Service Sector Shares in Selected Economies

\begin{tabular}{|c|c|c|c|c|c|}
\hline & \multirow{3}{*}{$\begin{array}{l}\text { Per capita } \\
\text { GNI } \\
\text { (US\$, 2003) }\end{array}$} & \multicolumn{4}{|c|}{ Service shares } \\
\hline & & \multicolumn{2}{|c|}{ GDP } & \multicolumn{2}{|c|}{ Employment } \\
\hline & & 1997 & 2003 & 1997 & 2004 \\
\hline China & 1,100 & 36 & 40 & 26 & 31 \\
\hline India & 540 & 48 & 53 & 25 & 28 \\
\hline Germany & 25,270 & 53 & 69 & 62 & 67 \\
\hline Japan & 34,180 & 58 & 68 & 62 & 67 \\
\hline UK & 28,320 & 60 & 72 & 72 & 76 \\
\hline US & 37,870 & 64 & 75 & 74 & 78 \\
\hline
\end{tabular}

Notes and soureces: China's GDP shares are guesstimates using the recently released economic survey data. China's employment shares are based on data from the National Bureau of Statistics (2005). The 2004 employment shares for Germany, Japan, UK and US are from the OECD (2005). Indian data are from the Reserve Bank of India (2005). The 2004 employment share for India is estimated by assuming the same rate of growth in the share in 1999 (the latest statistics available). Other statistics are drawn from Ono (2001) and the World Bank (2005). GNI represents gross national income.

The current momentum of growth in India's service sector will continue in the near future. However, growth in the manufacturing sector will be accelerated. This trend is already clearly demonstrated in the latest statistics. During the decade of 1994-2003, the manufacturing sector grew at an average annual rate of 6.6 per cent. This rate jumped to 8.1 and 9.0 per cent during the financial years of 2004-2005 and 2005-2006, respectively. ${ }^{18}$ The consequence of such growth is that the GDP shares of both the manufacturing sector and the service sector will expand at the cost of agriculture. For example, the GDP share of services is estimated to be 57.6 per cent by the end of the financial year of 2004-2005. The dilemma for India at present is that services accounted for more than a half of GDP but employed less than 30 per cent of the country's total work force (Table 3). These shares should match each other according to the experience of developed economies as cited in the preceding section. A study of the Pacific Basin countries also show that, without the concomitant progress of industrialization, growth in services in terms of both output and employment would not be sustainable (Park 1989).

\footnotetext{
18 The numbers are estimates by the Central Statistical Organisation quoted in Macroeconomic and Monetary Developments - First Quarter Review 2006-2007, the Reserve Bank of India (www.rbi.org.in), Mumbai.
} 
The same argument can be applied to India as well. In addition, to some extent, recent expansion in India's service sector is boosted by the IT service exports. But, the IT sector mainly employs the educated, urban youth, potentially leaving the majority of India's population further behind. Furthermore, the IT sector in India is relatively small (with a workforce under one million) and its rapid growth has not generated enough linkage with the rest of the economy as argued by Konana et al (2005). Thus, India will need growth in both services and manufacturing.

\section{CONCLUSION}

This paper reviewed and compared service sector development in China and India. It is found that the role of services in both economies has been rising with China starting on a lower base. Growth has mainly been driven by increasing specialization of production, rising standard of living and accelerated urbanization in both societies. There are also some non-economic factors which are difficult to be quantified in empirical analysis but have played important roles in service development in the two countries. These include biased development strategies in China, India's early linkage with the West and recent boom in Indian IT exports. India's service sector is now the dominant contributor to GDP growth but employment absorption is not very high in this sector. India's service sector will continue to grow. However, India needs industrialization even more as millions of rural workers have to be employed and as the IT sector is not large enough to significantly affect the growth of the national economy. In comparison with India, China's service sector is lagging behind. Even in international perspective, China's service sector is below the average. It can be anticipated that services will expand further as Chinese companies outsource their communications, legal and accounting services and as urbanization accelerates in the coming decades. In addition, the service sector has been the main provider of new jobs in China where there still exists a sizable pool of rural surplus labour to be shifted out of farming. 


\section{REFERENCES}

Bhagwati, Jagdish (1984), "Splintering and Disembodiment of Services and Developing Nations”, World Economy 7(2), 133-43.

Chanda, Rupa (2002), Globalization of Services: India's Opportunities and Constrains, Oxford University Press, New Delhi.

CSO (2005), On-line Database, National Accounts Division, Central Statistical Organization, Ministry of Statistics and Programme Implementation, Government of India (www.mospi.nic.in).

Desai, Meghnad (2003), “India and China: An Essay in Comparative Political Economy”, paper presented at the IMF Conference on India and China, Delhi, November.

Gordon, James and Poonam Gupta (2004), “Understanding India’s Services Revolution”, IMF Working Paper WP/04/171, International Monetary Fund, Washington DC.

Gupta, Chandra Prakash (1998), “India (1)”, in Improving Productivity in Service Sector, Asian Productivity Orangization, Tokyo.

Jiang, Xiaozhuan (ed) (2004), Service Industry in China: Growth and Structure, Social Sciences Documentation Publishing House, Beijing.

Konana, Prabhudev, John N. Doggett and Sridhar Balasubramanian (2005), “Advantage China”, Frontline 22(6), March.

Li, Jiangfan (ed) (2004a), The Economic Analysis of China's Tertiary Sector I, Guangdong People’s Press, Guangzhou.

Li, Jiangfan (ed) (2004b), The Economic Analysis of China's Tertiary Sector II, Guangdong People’s Press, Guangzhou.

Li, Shantong and Yongzhi Hou (eds) (2003), China’s WTO Accession and Service Trade, Shangwu Press, Beijing.

Li, Shantong, Yongzhi Hou, Yunzhong Liu and Jianwu He (2006), “Growth Prospects during 2006-2020”, in Economic Transition, Growth and Globalization in China edited by Yanrui Wu, Edward Elgar Publishing, Cheltenham, England, and, Northampton, USA.

Luo, Yadong (2001), China's Service Sector: A New battlefield for International Corporations, Copenhagen Business School Press, Copenhagen. 
Mohan, Pratibha (1998), “India (2)”, in Improving Productivity in Service Sector, Asian Productivity Orangization, Tokyo.

Mulder, Nanno (2001), “The Economic Performance of the Service Sector in Brazil, Mexico and the United States”, in Services in the International Economy edited by Robert M. Stern, Ann Arbor: The University of Michigan Press, chapter 8, pp.185-210.

National Bureau of Statistics (various issues), China's Statistical Yearbook, published annually by China Statistics Press, Beijing.

Ochel, Wolfgang and Manfred Wegner (1987), Service Economies in Europe: Opportunities for Growth, Pinter Publishers, London and Westview Press, Boulder, Colorado.

OECD (2005), OECD in Figures, 2005 edition, online (www.oecd.org).

Ono, Hisashi (2001), “Restructuring Strategy of Japan’s Service Sector in the TwentyFirst Century”, in Industrial Restructuring in East Asia edited by Seiichi Masuyama, Donna Vandenbrink and Chia Siow Yue, Nomura Research Institute, Tokyo, Japan, and Institute of Southeast Asian Studies, Singapore.

Park, Se-Hark (1989), “Linkages between Industry and Services and Their Implications for Urban Employment Generation in Developing Countries”, Journal of Development Economics 30, 359-79.

Qin, Duo (2004), “Is the Rising Services Sector in the People's Republic of China Leading to Cost Disease”, ERD Working Paper No. 50, Asian Development Bank, Manila.

Reserve Bank of India (2005), "Handbook of Statistics on Indian Economy”, on-line database (www.rbi.org.in).

Wilson, D. and R. Purushothaman (2003), "Dreaming with BRICs: the Path to 2050”, Global Economics Paper No.99, Goldman Sachs (www.gs.com).

Wirtz, Jochen (2000), "Growth of the Service Sector in Asia”, Singapore Management Review 22(2), pp.37-54.

Wolfl, Anita (2005), “The Service Economy in OECD Countries” in Enhancing the Performance of the Service Sector, OECD, Paris. 
Wong, John and Ruobing Liang (2003a), “China’s Service Industry (I): Growth and Structural Change”, EAI Background Brief No.162, East Asian Institute, National University of Singapore.

Wong, John and Ruobing Liang (2003b), “China’s Service Industry (I): Gearing Up for WTO Challenges”, EAI Background Brief No.163, East Asian Institute, National University of Singapore.

World Bank (2005), World Development Indicators 2005, the World Bank, Washingto DC.

Zhu, Jianhong (2005), “On economic aggregate and structural changes by the chief of the National Bureau of Statistics”, People’s Daily, December 21, p.5. 